\title{
Cervical collagen and biomechanical strength in non-pregnant women with a history of cervical insufficiency
}

Birgitte S Oxlund ${ }^{1 *}$, Gitte Ørtoft ${ }^{1}$, Annemarie Brüel ${ }^{2}$, Carl Christian Danielsen ${ }^{2}$, Hans Oxlund ${ }^{2}$, Niels Uldbjerg ${ }^{1}$

\begin{abstract}
Background: It has been suggested that cervical insufficiency $(\mathrm{Cl})$ is characterized by a "muscular cervix" with low collagen and high smooth muscle concentrations also in the non-pregnant state. Therefore, the aim of this study was to investigate the biomechanical properties, collagen concentration, smooth muscle cell density, and collagen fiber orientation in cervical biopsies from non-pregnant women with a history of $\mathrm{Cl}$.

Methods: Cervical punch biopsies $(2 \times 15 \mathrm{~mm})$ were obtained from 57 normal non-pregnant women and 22 women with a history of $\mathrm{Cl}$. Biomechanical tensile testing was performed, and collagen content was determined by hydroxyproline quantification. Histomorphometry was used to determine the volume densities of extracellular matrix and smooth muscle cells from the distal to the proximal part of each sample. Smooth muscle cells were identified using immunohistoche-mistry. Finally, collagen fiber orientation was investigated. Data are given as mean $+/$ - SD.

Results: Collagen concentration was lower in the Cl group (58.6+/- 8.8\%) compared with the control group $(62.2+/-6.6 \%)(p=0.033)$. However, when data were adjusted for age and parity, no difference in collagen concentration was found between the two groups. Maximum load of the specimens did not differ between the groups ( $p=0.78$ ). The tensile strength of cervical collagen, i.e. maximum load normalized per unit collagen (mg of collagen per $\mathrm{mm}$ of specimen length), was increased in the $\mathrm{Cl}$ group compared with controls ( $p=0.033)$. No differences in the volume density of extracellular matrix or smooth muscle cells were found between the two groups. Fibers not oriented in the plane of sectioning were increased in $\mathrm{Cl}$ patients compared with controls.

Conclusions: Cervical insufficiency does not appear to be associated with a constitutionally low collagen concentration or collagen of inferior mechanical quality. Furthermore, the hypothesis that a "muscular cervix" with an abundance of smooth muscle cells contributes to the development of cervical insufficiency is not supported by the present study.
\end{abstract}

\section{Background}

Various definitions of cervical insufficiency (CI) have been suggested. Of those, the most prominent include the following: 1) an inability of the uterine cervix to retain a pregnancy in the absence of uterine contractions [1]; and 2) a painless, progressive dilatation and effacement of the cervix that may lead to second trimester abortions or preterm delivery [2]. The latter may be the more clinically applicable. However, CI remains a

\footnotetext{
* Correspondence: boxlund@dadlnet.dk

'Department of Obstetrics and Gynecology, Aarhus University Hospital,

Skejby, DK-8200 Aarhus N, Denmark

Full list of author information is available at the end of the article
}

diagnosis of exclusion because the pathophysiology of CI remains unknown. Furthermore, CI might be seen as an extended biological continuum with degrees of cervical competence [3], replacing the traditional dichotomous view of cervical competence as being present or absent. However, it is well established that changes in connective tissue are important in the process of cervical ripening and remodeling [4] as the normal cervix is dominated by connective tissue rich in collagen, with only $15 \%$ muscle cells [5].

One hypothesis describes CI as a pregnancy-induced preterm cervical ripening involving increased inflammatory response, characterized by the up regulation of

\section{() Biomed Central}


cytokines, prostaglandins and matrix metalloproteinases $[6,7]$. This hypothesis is supported by a study showing that polymorphisms in the promoter region of the interleukin 10 (IL-10) gene are more common in women with CI than controls [8].

Another hypothesis explains CI as a constitutional defect in the cervical tissue, present in both the nonpregnant and pregnant states. A general connective tissue defect is seen in patients with Ehlers-Danlos syndrome [9] (Classical EDS, which results from mutations in the COL5A1 gene $[10,11])$, who deliver preterm due to $\mathrm{CI}$ or as polymorphisms in the collagen $1 \mathrm{~A} 1$ gene (COL1A1) found in CI patients [12]. Furthermore, hypotheses on localized cervical defects such as decreased collagen concentration [13-15], elastic fiber content [16] or increased smooth muscle cells (the "muscular cervix" $[17,18]$ ) have been suggested.

The aim of the present study was to investigate the hypothesis that $\mathrm{CI}$ is caused by a constitutional defect in the cervical tissue also present in a non-pregnant state. We hypothesize that non-pregnant women with a history of CI have decreased cervical collagen concentration, decreased biomechanical strength of the cervical tissue and increased smooth muscle cells compared with women who delivered at term.

\section{Methods}

This study was approved by the Local Research Ethical Committee (Region of Midtjylland, journal number: 20040195) and conducted in accordance with the Declaration of Helsinki 2008. In the present study the following definition of $\mathrm{CI}$ was used: a painless dilatation of the cervix in the second trimester of pregnancy, with no contractions of the uterus and no vaginal bleeding.

\section{Study population}

This case-control study included fifty-seven normal nonpregnant women (Table 1), admitted for sterilization (results on biomechanical properties and collagen concentration within this group was previously published [19]), as well as 22 non-pregnant women with a history of CI (Table 2). Exclusion criteria for controls were as follows: history of preterm delivery, conization, cervical laceration, cervical dysplasia, menopause, and connective tissue disorders. At five hospitals (Aarhus, Hvidovre, Viborg, Aalborg and Randers Hospital), 662 patients were identified by ICD10 diagnosis (cervical incompetence), as well as by the procedure, 'cerclage', or short length of the cervix $(<2.5 \mathrm{~cm}) .599$ patients were excluded due to unfulfilled diagnostic criteria for $\mathrm{CI}$, at least one normal birth, signs of infection, previous conization, cervical dysplasia, twin pregnancy or incomplete history. The remaining 66 patients were contacted, and
22 accepted to participate in the study and were included. The period of time elapsed from last birth (controls) or CI to biopsies were taken as follows: controls, 6 years (range 1/2-19 years); and CI, 2 years (range $1 / 2-9$ years).

\section{Tissue collection}

Long, narrow biopsies of cervical tissue (approximately $15 \times 2 \mathrm{~mm}$ ) were punched out parallel to the cervical canal, halfway between the external os and the lateral surface of the cervix, with an instrument of external diameter 3 mm (Miltex ${ }^{\circ}$, Dermal Biopsy Punch, Germany). Three biopsies were obtained from each patient at the 3, 6 and 12 o'clock positions. Hemostasis was secured by compression or if necessary with el-coagulation or a stitch. No complications were observed apart from slight vaginal bleeding. As a single biopsy was obtained from one patient in the control group, it was included in the histological part of the study only and not in the biomechanical testing.

Two biopsies were immersed in Ringer's solution and immediately frozen at $-80^{\circ} \mathrm{C}$ until biomechanical testing, and the third biopsy was divided into a proximal and a distal portion. The proximal portion, approximately $5 \mathrm{~mm}$ long, was used for later genetic studies. The distal part including the epithelium, approximately $10 \mathrm{~mm}$ long, was immersion fixed in $0.1 \mathrm{M}$ sodium phosphate-buffered $4 \%$ formaldehyde, $\mathrm{pH}$ 7.0, for 24 hours and stored in $70 \%$ ethanol until histological examination.

\section{Biomechanical analysis}

The biomechanical analysis was performed on tissue samples from 56 women. Two biopsies from each patient were analyzed by means of a materials testing machine (Alwetron TCT5, Lorentzen \& Wettre, Kista, Sweden). The biopsies were thawed at room temperature, and the epithelium WAS removed using a dissecting microscope. Each sample was immersed in Ringer's solution ( $\mathrm{pH} 7.4$ ) and mounted between two clamps with a jaw space of $4 \mathrm{~mm}$. The tensile strength of specimens was tested by moving the clamps apart with a constant deformation rate $(10 \mathrm{~mm} / \mathrm{min})$, stretching the sample until breaking while a load-deformation curve was recorded.

From the load-deformation curve the following parameters were derived:

$\mathrm{F}_{\text {max }}$ : maximum load $(\mathrm{N})$; the maximum force used for breaking the specimen.

$\varepsilon-\mathrm{F}_{\max }:$ strain at maximum load; the specimen extensibility.

$\mathrm{S}_{\text {max }}$ : maximum load; normalized for collagen $(\mathrm{N} \times$ $\left.\mathrm{mm} \times \mathrm{mg}^{-1}\right)$. 
Table 1 Clinical data on the 57 control women

\begin{tabular}{|c|c|c|c|c|c|c|}
\hline $\begin{array}{l}\text { Patient } \\
\text { number }\end{array}$ & Age & $\begin{array}{l}\text { Termination of } \\
\text { pregnancy } \\
<12 \text { weeks }\end{array}$ & $\begin{array}{c}\text { Spontaneous abortion }<16 \\
\text { weeks }\end{array}$ & $\begin{array}{c}\text { Spontaneous abortions } 16 \text { to } 23 \\
+6 \text { weeks }\end{array}$ & $\begin{array}{l}\text { Cesarean } \\
\text { section }\end{array}$ & $\begin{array}{c}\text { Parity } \\
\text { Number of } \\
\text { deliveries }\end{array}$ \\
\hline 1 & 49 & 2 & - & - & - & 3 \\
\hline 2 & 48 & 1 & - & - & - & 3 \\
\hline 3 & 45 & - & 2 & - & - & - \\
\hline 4 & 36 & 1 & 2 & - & - & 3 \\
\hline 5 & 44 & - & - & - & - & 2 \\
\hline 6 & 30 & - & - & - & - & 2 \\
\hline 7 & 33 & 1 & - & - & 2 & 2 \\
\hline 8 & 41 & 1 & 1 & - & - & 2 \\
\hline 9 & 40 & 2 & - & - & - & 2 \\
\hline 10 & 33 & 1 & 1 & - & 1 & 2 \\
\hline 11 & 34 & - & 1 & - & 1 & 3 \\
\hline 12 & 41 & 1 & - & - & - & 3 \\
\hline 13 & 42 & 1 & - & - & - & 2 \\
\hline 14 & 34 & - & - & - & - & 2 \\
\hline 15 & 41 & 2 & - & - & - & 2 \\
\hline 16 & 30 & - & 1 & - & - & 2 \\
\hline 17 & 39 & 1 & - & - & - & 2 \\
\hline 18 & 41 & - & - & - & - & - \\
\hline 19 & 40 & 1 & - & - & - & 3 \\
\hline 20 & 38 & - & 1 & - & 1 & 2 \\
\hline 21 & 30 & - & 4 & - & - & 2 \\
\hline 22 & 41 & 2 & 1 & - & - & 3 \\
\hline 23 & 39 & 2 & - & - & - & 2 \\
\hline 24 & 38 & - & 1 & - & - & 3 \\
\hline 25 & 41 & - & 1 & - & - & 3 \\
\hline 26 & 40 & 1 & - & - & - & 1 \\
\hline 27 & 37 & - & - & - & - & 3 \\
\hline 28 & 41 & - & - & 1 & - & 3 \\
\hline 29 & 37 & - & - & - & 2 & 2 \\
\hline 30 & 32 & - & - & - & - & 2 \\
\hline 31 & 44 & - & 1 & - & - & 2 \\
\hline 32 & 42 & 1 & - & - & - & 4 \\
\hline 33 & 36 & 1 & - & - & - & 2 \\
\hline 34 & 42 & - & 2 & - & - & 4 \\
\hline 35 & 44 & - & 3 & - & - & 3 \\
\hline 36 & 33 & 2 & - & - & 2 & 3 \\
\hline 37 & 31 & - & - & - & - & - \\
\hline 38 & 43 & - & - & - & - & 1 \\
\hline 39 & 30 & - & 1 & - & 3 & 3 \\
\hline 40 & 31 & - & 1 & - & - & 3 \\
\hline 41 & 42 & - & - & - & - & 2 \\
\hline 42 & 42 & - & - & - & 1 & 1 \\
\hline 43 & 46 & 1 & - & - & - & 4 \\
\hline 44 & 39 & 1 & - & - & - & 3 \\
\hline 45 & 35 & 2 & 2 & - & 1 & 3 \\
\hline 46 & 38 & - & - & - & - & 4 \\
\hline 47 & 36 & - & - & - & 2 & 2 \\
\hline 48 & 42 & 1 & - & - & - & 1 \\
\hline 49 & 45 & - & - & - & - & - \\
\hline 50 & 42 & 1 & - & - & - & 3 \\
\hline
\end{tabular}


Table 1 Clinical data on the 57 control women (Continued)

\begin{tabular}{|c|c|c|c|c|c|c|}
\hline 51 & 31 & 1 & - & - & - & 2 \\
\hline 52 & 34 & - & 1 & - & - & 2 \\
\hline 53 & 41 & 1 & 1 & - & - & 3 \\
\hline 54 & 41 & - & - & - & 1 & 2 \\
\hline 55 & 30 & - & - & - & - & - \\
\hline 56 & 39 & 1 & 1 & - & - & 3 \\
\hline 57 & 29 & - & - & - & - & 3 \\
\hline
\end{tabular}

All women had normal pregnancies and deliveries at term

$\mathrm{S}_{\text {max }}$ : maximum stiffness; normalized for collagen $\left(\mathrm{N} \times \mathrm{mm} \times \mathrm{mg}^{-1}\right)$.

$\mathrm{F}_{\max }$ and $\varepsilon-\mathrm{F}_{\max }$ imply the biomechanical characteristics of the specimen, whereas $S_{\max }$ and $S_{\text {max }}^{\prime}$ imply the characteristics of the collagen component.

\section{Determination of hydroxyproline}

After mechanical analysis, the tissue between the clamps was used for hydroxyproline determination. The tissue was defatted in acetone, and after freeze-drying the dry defatted weight (DDW) was determined. The tissue was then hydrolyzed in $6 \mathrm{M} \mathrm{HCl}$ for $16 \mathrm{~h}$ at $100^{\circ} \mathrm{C}$. Subsequently, the hydroxyproline content was measured according to Woessner [20] with modifications as described in [21]. The collagen content was calculated by multiplying the hydroxyproline content by 7.46 [22].

\section{Immunohistochemistry}

Immunohistochemistry was used to detect smooth muscle cells. The tissue biopsies were embedded in paraffin, and 2- $\mu \mathrm{m}$-thick sections parallel to the long axis were cut and mounted two sections per slide. The sections were deparaffinized and endogenous peroxidase blocked by $0.5 \% \mathrm{H}_{2} \mathrm{O}_{2}$ in absolute methanol. In order to reveal antigens, sections were boiled for 10 min in $0.1 \mathrm{mM}$ Tris/ $\mathrm{HCl}$ and $0.5 \mathrm{mM}$ EGTA, pH 9. Non-specific binding was blocked by $1 \%$ BSA (bovine serum albumin). Sections were incubated overnight at $4^{\circ} \mathrm{C}$ with a primary antibody against smooth muscle actin (1:1600, monoclonal mouse anti-human, M0851, DAKO, Denmark) diluted in PBS supplemented with $0.1 \%$ BSA and $0.3 \%$ Triton-X100. Negative controls were incubated with mouse serum or IgG1 instead of primary antibody. After washing, the sections were incubated with horseradish peroxidase-conjugated secondary antibody (goat anti-mouse, P0447, DAKO, Denmark), for $1 \mathrm{~h}$ at $20^{\circ} \mathrm{C}$. The peroxidase was visualized by reaction with $0.05 \%$ 3,3'-diaminobenzidine tetrahydrochloride dissolved in PBS with $0.1 \% \mathrm{H}_{2} \mathrm{O}_{2}$ before counterstaining with Mayer's Haematoxylin and alcoholic eosin. Sections with muscular arteries were used as positive controls.

\section{Estimation of the volume density of extracellular matrix (ECM) and muscle cells}

For the histomorphometry a modified Olympus BH-2 microscope with a motorized stage was used, combined with a video camera (JAI-2040, Kanagawa, Japan). By means of CAST software (Olympus, Denmark), counting frames were superimposed onto live images of the tissue sections. The fields of view in each section were sampled using systematic, uniformly random sampling (SURS) [23]. From a random starting point, a new field of view with fixed $\mathrm{x}$ and $\mathrm{y}$ distance from the previous field was sampled by means of a motorized specimen stage. From each patient two immunostained sections were evaluated. The epithelium was used to determine the sample orientation. Each section was divided into three or four $2 \mathrm{~mm}$ sites, depending on biopsy length (i.e. sites I-IV: 0-2, 2-4, 4-6, 6-8 $\mathrm{mm}$ from the epithelium, respectively).

Only sections with detectable epithelium were included in this analysis (controls: $n=50, C I: n=14$ ). In each section approximately 36 fields of view were evaluated using a counting grid of 81 points. The number of points hitting ECM (defined as non-cellular components), smooth muscle cells (positive for smooth muscle actin), nuclei associated with the connective tissue and blood vessels (with a visible lumen, vessel wall and at times, also blood cells) were counted. The volume density was evaluated for the whole section (all 57 patients included). For sections with detectable epithelium, individual sites I-IV were evaluated as described above (a reduced number of patients were included due to lack of visible epithelium). Counting took place at a final magnification of $\times 1263$. The evaluation of sections was blinded.

\section{Determination of collagen orientation}

Collagen orientation was determined by microscopy (Olympus BX40) with live video imaging (Nikon DS-Fi1) connected to a monitor (Sony Multiscan G200). Nikon NIS-Elements F 3.00 software was used. Three $\mu \mathrm{m}$ thick sections were cut parallel to the long axis of the biopsies and stained with Picro-Sirius [24]. The sections were 
divided into two portions, of which the proximal portion, corresponding to the part used for mechanical analysis, was used to determine collagen orientation. The epithelium was used to determine section orientation. Only sections with detectable epithelium were included (controls: $n=42, C I: n=15$ ). A grid was constructed and physically mounted on the computer monitor. With the longitudinal axis of horizontal sections, collagen fibers at least $27 \mu \mathrm{m}$ long were divided into three categories based on their orientation: 1) fibers deviating less than $\pm 45^{\circ}$ from the longitudinal axis; 2) fibers deviating between $46^{\circ}$ and $90^{\circ}$ or $-46^{\circ}$ to $-90^{\circ}$ from the longitudinal axis; and 3) fibers shorter than $27 \mu \mathrm{m}$ long (indicating that they are not oriented parallel with the sectioning plane). Two sections from each patient were evaluated at a total magnification of $\times 1115$. For each section, collagen orientation was determined at four points within each of 25 randomly (manually) selected fields of view. As above, the evaluation of the sections was blinded.

\section{Statistical analyses}

Data are given as mean \pm SD. Comparisons of parameters between the two groups were performed using Students t-test. If necessary, data were log-transformed to comply with the assumption of the statistical method. Linear regression was performed to describe the relationship between a pair of parameters. Multiple linear regression was used to adjust parameters for age and parity. Repeated Measures ANOVA was performed to compare different sites of the histological sections between groups, whereas Test for trend was used to describe a steadily increase or decrease throughout the biopsy. Differences were considered significant when $\mathrm{p}<$ 0.05. The statistical packages SigmaStat 3.5 and STATA intercooled 9 were used.

\section{Results}

\section{Collagen and biomechanical analyses}

Collagen concentration was 3.7\% lower in the CI-group $(58.6 \pm 8.8 \%)$ (Table 3$)$ compared with the control group $(62.2 \pm 6.6 \%)(\mathrm{p}=0.033)$ (Figure 1). However, as a statistical difference in age and parity was found between the two groups (Table 4), data were adjusted for age and parity. A previous study has shown that the collagen concentration increased $0.5 \%$ per year of age and decreased $1.7 \%$ per birth [19]. The difference between the two groups was $4.2 \%(\mathrm{p}=0.02)$ when adjusted for parity alone, whereas it was $1.6 \%(\mathrm{p}=0.32)$ when adjusted for age alone. When adjusted for both age and parity, it was $2.2 \%$ and no longer statistically significant $(\mathrm{p}=0.2)$. From these calculations, $43 \%$ of the determined difference can be explained due to age, whereas $57 \%$ is due to other factors. When collagen concentration in parous women (control group without the 5 nullipara) was compared with the CI group, no difference in collagen concentration was found $(\mathrm{p}=$ 0.083).

Second trimester abortions may have the same impact on the cervical collagen concentration as deliveries. When categorizing the second trimester abortions as deliveries, no difference in collagen concentration was found (adjustment for age, parity and second trimester abortions, $\mathrm{p}=0.41$ ).

To evaluate the hypothesis that $\mathrm{CI}$ is caused by a biomechanically weak cervix, the biomechanical properties of cervical tissue samples were investigated. Maximum load $\left(\mathrm{F}_{\max }\right)$ was proportional to collagen content both in the control group and the CI group (Figure 2). No difference in maximum load $\left(\mathrm{F}_{\max }\right)$ of the biopsies was found between the two groups.

In order to describe the tensile strength of cervical collagen, maximum load was divided by collagen content in $\mathrm{mg}$ of collagen per $\mathrm{mm}$ of specimen length. This normalized maximum load $\left(S_{\max }\right)$ was found to be significantly increased in the CI group compared with controls (Figure 3). Similarly, the normalized maximum stiffness $\left(S^{\prime}{ }_{\max }\right)$ was determined, but no difference was found between the two groups. However, when values were adjusted for age and parity, the maximum stiffness normalized for collagen was found to be increased in the CI group ( $\mathrm{p}=0.008$; Table 3$)$. No difference in extensibility $\left(\varepsilon-\mathrm{F}_{\max }\right)$ of the biopsies was found when comparing the two groups. DDW varied considerable, but no significant difference was found between the two groups (CI: $1.90 \pm 0.82 \mathrm{mg}$, controls: $2.13 \pm 0.69 \mathrm{mg}$ (p $=0.22)$ ).

\section{Histomorphometry}

To evaluate the hypothesis on the "muscular cervix", the volume density of ECM, smooth muscle cells, connective tissue nuclei, and blood vessel were determined (Table 5); however, no difference was found between the two groups. The sections were divided into site I (distal part, near the epithelium), II, III and IV (proximal part). In both controls and CI the volume density of smooth muscle cells was increased from distal to proximal part of the biopsies (Controls: $8.9 \pm 6.7$ to $13.9 \pm$ $6.2 \%(\mathrm{p}<0.001), \mathrm{CI}: 5.2 \pm 3.0 \%$ to $12.0 \pm 5.6 \%(\mathrm{p}<$ $0.001))$.

\section{Collagen fiber orientation}

Collagen fiber orientation was determined in order to evaluate whether the increase in normalized load found in the CI group could be explained from a different orientation of collagen fibers. The percentage of collagen fibers which was not oriented in the plane of sectioning was increased in CI patients $(48.5 \pm 13.2 \%)$ 
Table 2 Clinical data on the 22 non-pregnant women with a history of cervical insufficiency

\begin{tabular}{|c|c|c|c|c|c|c|c|c|c|}
\hline \multirow{2}{*}{$\begin{array}{c}\text { Patient number } \\
1\end{array}$} & \multirow{2}{*}{$\begin{array}{c}\text { Age } \\
29\end{array}$} & \multicolumn{2}{|c|}{$\begin{array}{c}\text { Termination of pregnancy } \\
\text { before week } 12\end{array}$} & \multicolumn{2}{|c|}{$\begin{array}{c}\text { Spontaneous abortion } \\
<16 \text { weeks }\end{array}$} & \multicolumn{2}{|c|}{$\begin{array}{c}\text { Spontaneous abortions } 16 \\
\text { to } 23+6 \text { weeks }\end{array}$} & \multicolumn{2}{|c|}{$\begin{array}{c}\text { Births ( } \geq 24 \text { weeks) gestational } \\
\text { age }\end{array}$} \\
\hline & & & - & & - & I & $23+$ & $\|$ & $27+$ \\
\hline 2 & 37 & & - & & - & & - & । & $27+(C S)$ \\
\hline 3 & 37 & & - & & - & I & $22+$ & $\|$ & $37+(\mathrm{Mc}-\mathrm{C})$ \\
\hline \multirow[t]{2}{*}{4} & 39 & । & $8+$ & III & Un & $\|$ & $20+$ & IV & $38+(\mathrm{Mc}-\mathrm{C})$ \\
\hline & & & & V & Un & $\mathrm{VI}$ & $17+$ & VII & $36+(\mathrm{Mc}-\mathrm{C})$ \\
\hline \multirow[t]{2}{*}{5} & 27 & & - & & - & । & $22+$ & $\|$ & $34+(\mathrm{Abd}-\mathrm{C}, \mathrm{CS})$ \\
\hline & & & & & & & & III & $38+(\mathrm{Abd}-\mathrm{C}, \mathrm{CS})$ \\
\hline \multirow[t]{3}{*}{6} & 30 & & - & & - & & - & । & $24+(C S)$ \\
\hline & & & & & & & & $\|$ & $37+(\mathrm{Mc}-\mathrm{C})$ \\
\hline & & & & & & & & III & $36+(M c-C, C S)$ \\
\hline \multirow[t]{3}{*}{7} & 36 & & - & । & $7+$ & III & $23+$ & $\|$ & $25+$ \\
\hline & & & & & & & & IV & $33+(\mathrm{Mc}-\mathrm{C})$ \\
\hline & & & & & & & & V & 35 (Abd-C, CS) \\
\hline \multirow[t]{2}{*}{8} & 33 & & - & $\|$ & $15+$ & & - & । & $25+$ \\
\hline & & & & & & & & III & $38+(\mathrm{Mc}-\mathrm{C})$ \\
\hline \multirow[t]{2}{*}{9} & 30 & & - & । & $6+$ & $\|$ & 21 & III & $37+(\mathrm{Abd}-\mathrm{C}, \mathrm{CS})$ \\
\hline & & & & & & & & IV & $36+(\mathrm{Abd}-\mathrm{C}, \mathrm{CS})$ \\
\hline \multirow[t]{2}{*}{10} & 36 & I & $6+$ & $\|$ & $8+$ & III & $19+$ & IV & $24+$ \\
\hline & & & & & & & & V & $36+(\mathrm{Abd}-\mathrm{C}, \mathrm{CS})$ \\
\hline 11 & 31 & & - & I & $12+$ & $\|$ & $23+$ & III & $39+(\mathrm{Mc}-\mathrm{C})$ \\
\hline \multirow[t]{2}{*}{12} & 38 & & - & & - & । & $22+$ & $\|$ & $37+(\mathrm{MC}-\mathrm{C}, \mathrm{CS})$ \\
\hline & & & & & & & & III & $37+(\mathrm{Mc}-\mathrm{C})$ \\
\hline \multirow[t]{2}{*}{13} & 32 & $\|$ & $6+$ & & - & & - & । & $24+(C S)$ \\
\hline & & & & & & & & III & $35+(\mathrm{Mc}-\mathrm{C})$ \\
\hline 14 & 26 & & - & & - & । & $21+$ & $\|$ & $38+(\mathrm{McC})$ \\
\hline \multirow[t]{3}{*}{15} & 43 & & - & & - & & - & । & $25+$ \\
\hline & & & & & & & & $\|$ & $36+(\mathrm{Mc}-\mathrm{C})$ \\
\hline & & & & & & & & III & $38+(\mathrm{Mc}-\mathrm{C})$ \\
\hline \multirow[t]{3}{*}{16} & 37 & I & $7+$ & $\|$ & $8+$ & & - & V & 36+ (Emer-C week 22) \\
\hline & & & & III & $7+$ & & & $\mathrm{VI}$ & $38+(\mathrm{Mc}-\mathrm{C})$ \\
\hline & & & & IV & $8+$ & & & & \\
\hline \multirow[t]{4}{*}{17} & 43 & I & $6+$ & $\|$ & $14+$ & V & $23+$ & $\mathrm{VI}$ & $39+(\mathrm{Mc}-\mathrm{C})$ \\
\hline & & & & III & $10+$ & & & VII & $39+(\mathrm{Mc}-\mathrm{C})$ \\
\hline & & & & IV & $9+$ & & & IX & $38+(\mathrm{Mc}-\mathrm{C})$ \\
\hline & & & & VIII & $13+$ & & & $x$ & $40+(\mathrm{Mc}-\mathrm{C})$ \\
\hline \multirow[t]{2}{*}{18} & 40 & । & $6+$ & III & $7+$ & IV & $21+$ & & - \\
\hline & & $\|$ & $8+$ & $\mathrm{Vl}$ & $6+$ & V & $16+$ & & \\
\hline 19 & 29 & & - & - & & & - & I & 28+ ( Emer-C week 19+4) \\
\hline 20 & 25 & & - & - & & & - & । & $26+(C S)$ \\
\hline 21 & 31 & & - & - & & । & $22+$ & $\|$ & 37 (Mc-C) \\
\hline \multirow[t]{2}{*}{22} & 39 & & - & I & $7+$ & III & $21+$ & - & \\
\hline & & & & $\|$ & $8+$ & & & & \\
\hline
\end{tabular}

$\mathrm{I}-\mathrm{X}$ : The sequence of the pregnancies $8+, 16+$ etc: Gestational age in weeks Mc-C: Elective Mc Donald cerclage Abd-C: Abdominal cerclage Emer-C: Emergency cerclage on dilated or very short cervix CS: Cesarean section Un: Unknown gestational age 
Table 3 Biomechanical and biochemical data

\begin{tabular}{|c|c|c|c|c|}
\hline & Control & $\mathrm{Cl}$ & $\begin{array}{c}\text { Control vs. } \\
\mathrm{Cl}\end{array}$ & $\begin{array}{c}\text { Adjusted } \\
\text { values } \\
\text { Control vs. } \\
\mathrm{Cl}^{*}\end{array}$ \\
\hline Total number & 56 & 22 & & \\
\hline $\begin{array}{l}\text { Collagen \% (of } \\
\text { DDW) }\end{array}$ & $\begin{array}{c}62.2 \pm \\
6.6\end{array}$ & $\begin{array}{l}58.6 \pm \\
8.8\end{array}$ & $p=0.033$ & $p=0.200$ \\
\hline Collagen $(\mathrm{mg} / \mathrm{mm})$ & $\begin{array}{c}0.26 \pm \\
0.1\end{array}$ & $\begin{array}{l}0.22 \pm \\
0.13\end{array}$ & $p=0.059$ & $p=0.835$ \\
\hline $\mathrm{F}_{\max }(\mathrm{N})$ & $4.0 \pm 1.7$ & $4.1 \pm 2.2$ & $p=0.778$ & $p=0.335$ \\
\hline $\begin{array}{l}\mathrm{S}_{\max }(\mathrm{N} \times \mathrm{mm} \times \\
\left.\mathrm{mg}^{-1}\right)\end{array}$ & $\begin{array}{c}15.8 \pm \\
4.4\end{array}$ & $\begin{array}{l}19.0 \pm \\
6.8\end{array}$ & $p=0.033$ & $p<0.001$ \\
\hline $\begin{array}{l}\mathrm{S}_{\max }^{\prime}(\mathrm{N} \times \mathrm{mm} \times \\
\left.\mathrm{mg}^{-1}\right)\end{array}$ & $\begin{array}{c}64.4 \pm \\
21.9\end{array}$ & $\begin{array}{c}77.3 \pm \\
34.9\end{array}$ & $p=0.096$ & $p=0.008$ \\
\hline$\varepsilon-F_{\max }$ & $\begin{array}{c}0.49 \pm \\
0.1\end{array}$ & $\begin{array}{c}0.49 \pm \\
0.1\end{array}$ & $p=0.914$ & $p=0.212$ \\
\hline
\end{tabular}

Biomechanical and biochemical parameers of cervical samples from women with a history of $\mathrm{Cl}$ and controls

Data are given as mean \pm SD

*Values adjusted for age and parity

compared with control $(40.6 \pm 11.6 \%)(\mathrm{p}=0.033)$ (Table $6)$. No differences between the two groups in the percentage of collagen fibers considered "parallel" (less than $\pm 45^{\circ}$ ) with (Figure $4 \mathrm{~A}$ and $4 \mathrm{~B}$ ) or "perpendicular" (between $46^{\circ}$ and $90^{\circ}$ or $-46^{\circ}$ to $-90^{\circ}$ ) to the longitudinal axis were found.

\section{Discussion}

The present study does not support the hypothesis that CI is caused by a constitutional "muscular cervix" $[17,18]$ with low collagen concentration present in both nonpregnant and pregnant states. We found the collagen concentration only marginally and not statistically

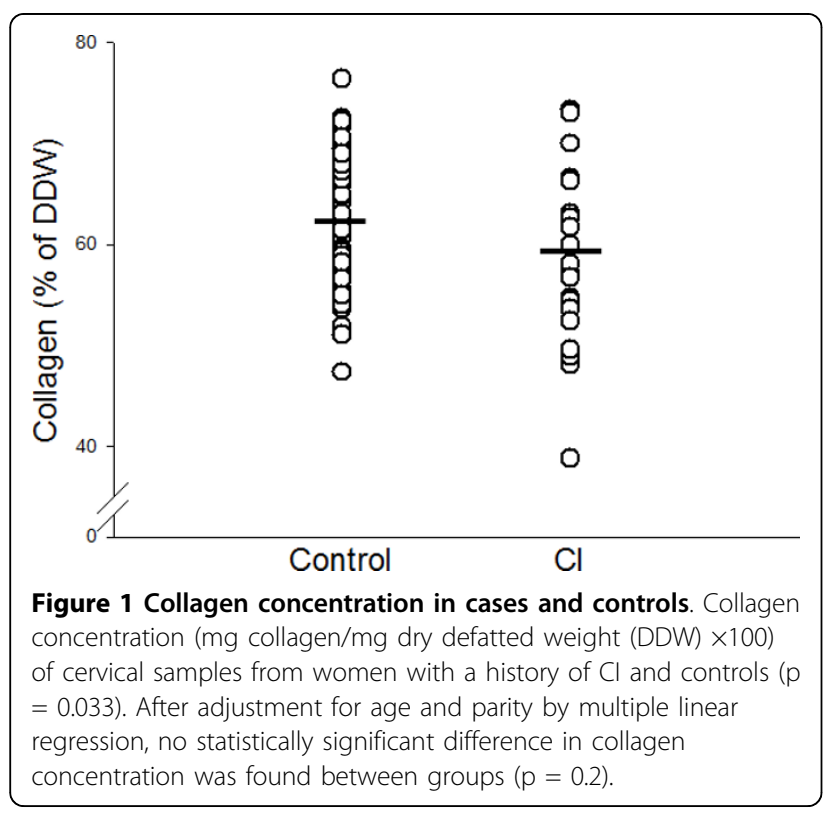

Table 4 Clinical characteristics of controls and cases

\begin{tabular}{lcc}
\hline & Control & Cl \\
\hline Total number & 57 & 22 \\
Age (years) & $38.3 \pm 5.1$ & $34.0 \pm 5.3^{*}$ \\
mean \pm SD & $2.3 \pm 1.0$ & $1.7 \pm 1^{* *}$ \\
Parity (numbers of births) & & \\
mean \pm SD & $35 \%$ & $45 \%$ \\
Spontaneous abortions (<week 16) & $2 \%$ & $59 \%$ \\
Spontaneous abortions 16 to 23+6 weeks & $46 \%$ & $27 \%$ \\
Termination of pregnancy & & \\
(before week 12) & $19 \%$ & $41 \%$ \\
Cesarean section & 0 & $95 \%$ \\
Cerclage &
\end{tabular}

Percentage of women who experienced one or more i.e. abortions ${ }^{*} \mathrm{p}=0.02$ against control

${ }^{* *} \mathrm{p}=0.012$ against control

significantly decreased in non-pregnant women with a history of CI, and neither the biomechanical nor the histomorphometrical examinations supported the hypothesis. The only differences among the CI patients as compared to controls were increased collagen tensile strength and stiffness $\left(S_{\max }\right.$ and $\left.S_{\max }^{\prime}\right)$ and increased proportion of collagen fibers not oriented in the plane of sectioning.

Our results on collagen concentration disagree with those of Petersen et al., who found a 15\% decreased cervical collagen concentration in non-pregnant CI-women [13], but agree with those of Rechberger et al., who examined early second trimester cervical biopsies from CI-women [25]. We cannot explain these disparities. The muscular cervix hypothesis is based on histological examinations of cervical biopsies taken immediately after delivery [18]. The mean muscle concentration was

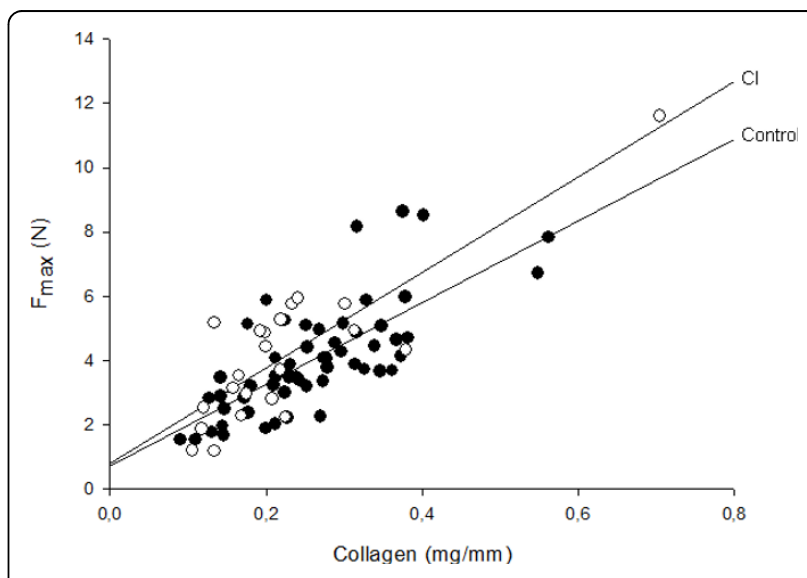

Figure $2 \mathbf{F}_{\max }$ versus collagen content. Maximum load $\left(F_{\max }\right)$ of cervical samples in relation (linear regression) to collagen content $\mathrm{mg} / \mathrm{mm}$. Filled circle: Control $(r=0.76, p<0.001)$. Open circle: $\mathrm{Cl}$ $(r=0.76, p<0.001)$ (Result on the control group has been submitted for publication 2009). 


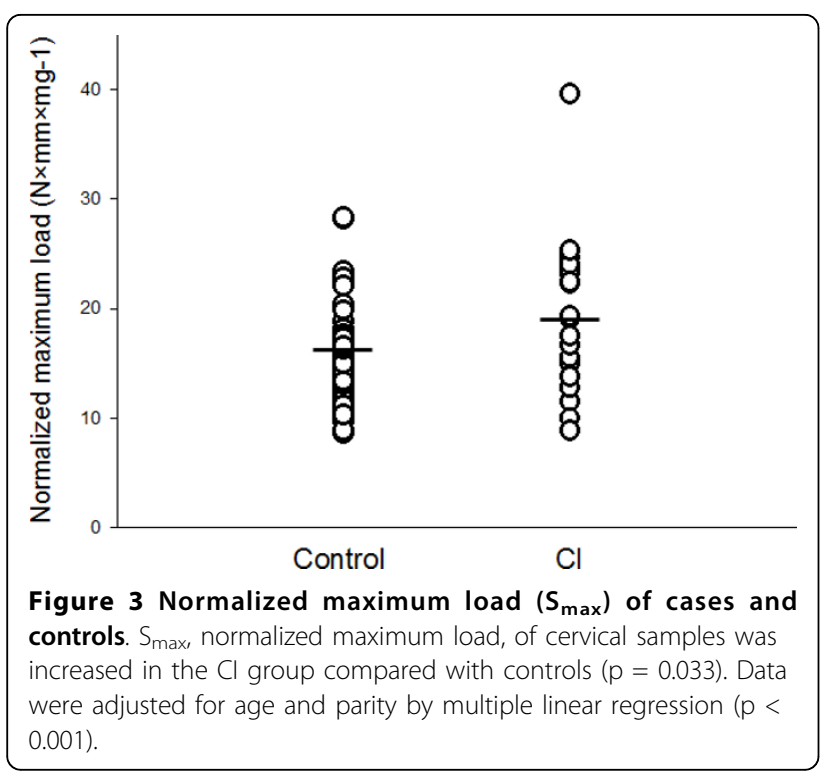

$9.3 \pm 5.9 \%$ in 45 controls and $22.3 \pm 8.0 \%$ in $12 \mathrm{CI}-$ patients. This finding from 1965 has been reproduced, but our results indicate that it cannot be extrapolated to the non-pregnant state.

The biomechanical properties of a tissue are determined not only by the collagen concentration but also by the collagen composition, the cross links, and the presence of other extracellular macromolecules like decorin and versican [26] whereas muscle cells only contribute insignificantly [27]. It is, therefore, interesting that Warren et al. [12] found increased frequency of the TT genotype in the COL1A1 gene among CI-patients, a

\section{Table 5 Histomorphometry}

\begin{tabular}{lcc}
\hline & Control & Cl \\
\hline Number of individuals & 57 & 22 \\
ECM \% & $76.2 \pm 7.1$ & $76.5 \pm 8.9$ \\
Muscle \% & $13.3 \pm 6.5$ & $11.9 \pm 7.8$ \\
Connective tissue nuclei \% & $4.4 \pm 1.5$ & $4.8 \pm 2.2$ \\
Blood vessels \% & $6.1 \pm 3.4$ & $6.7 \pm 2.8$ \\
ECM/muscle-ratio & $8.1 \pm 6.5$ & $9.0 \pm 5.0$
\end{tabular}

The volume density (\%) of cervical samples from women with a history of $\mathrm{Cl}$ and controls

Data are given as mean \pm SD

No significant difference in any of the investigated parameters were found between the two groups

\section{Table 6 Collagen orientation}

\begin{tabular}{lcc}
\hline & $\begin{array}{c}\text { Control } \\
\mathbf{n}=\mathbf{4 2}\end{array}$ & $\begin{array}{c}\mathbf{C l} \\
\mathbf{n}=\mathbf{1 5}\end{array}$ \\
\hline Less than $\pm 45^{\circ}$ & $36.8 \pm 9.6$ & $32.6 \pm 7.0$ \\
Between $46^{\circ}$ and $90^{\circ}$ or $-46^{\circ}$ to $-90^{\circ}$ & $22.4 \pm 9.7$ & $19.0 \pm 10.7$ \\
Fibers not oriented parallel with the & $40.6 \pm 11.6$ & $48.5 \pm 13.2^{*}$ \\
sectioning plane (shorter than $27 \mu \mathrm{m})$ & & \\
\hline
\end{tabular}

Orientation of collagen fibers in cervical samples from women with a history of $\mathrm{Cl}$ and controls. Mean $\pm \mathrm{SD}$

${ }^{*} p=0.033$ against control by students t-test

polymorphism associated with abnormal collagen triplehelix composition. We have not studied the COL1A1 gene in our population, but the increased $S_{\max }$, which indicates altered collagen properties in CI-patients, could reflect the findings by Warren et al. One could also speculate whether such triple-helix abnormalities cause the "coiling" of the collagen fibers and, thus, are not orientated in a specific direction as demonstrated in

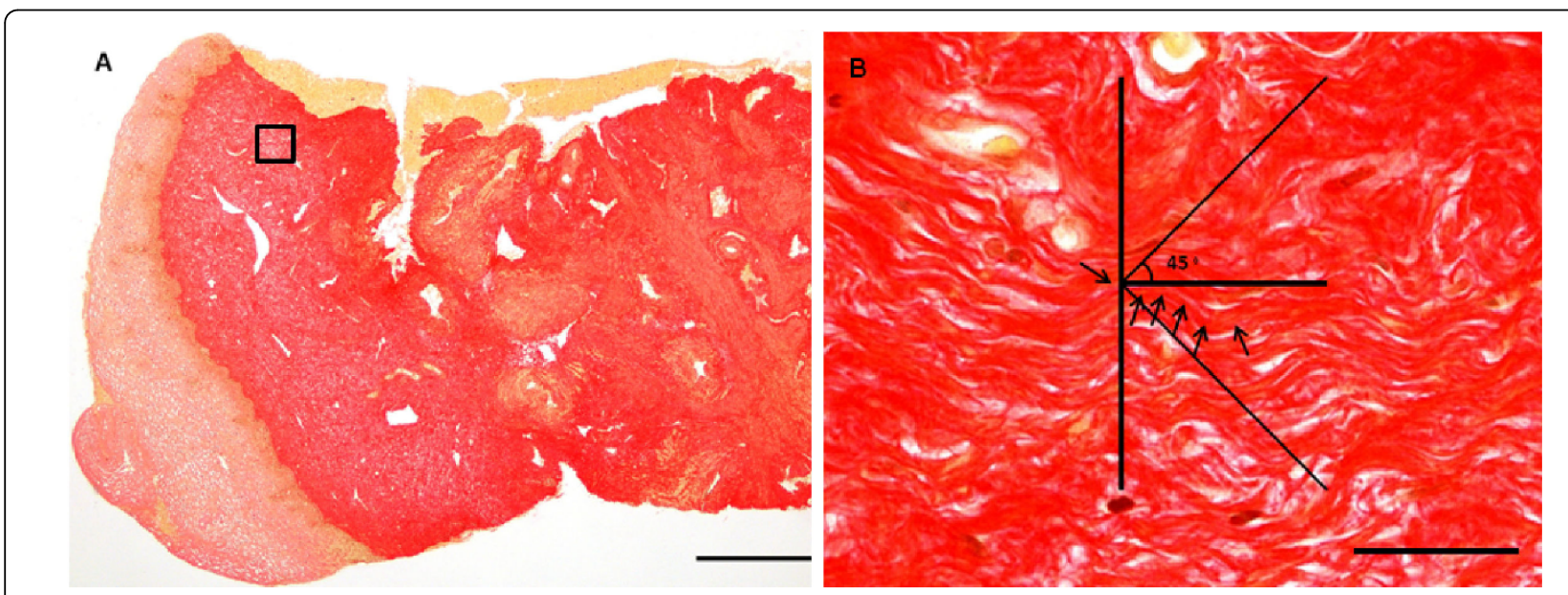

Figure 4 Collagen fiber orientation. Picro-Sirius stained sections from the human cervix. (A) Longitudinal section of a biopsy including epithelium (Bar: $500 \mu \mathrm{m}$ ); (B) collagen fibers in the center of the grid were divided into three categories based on their orientation (longitudinal axis of sections horizontal): 1) longitudinal or "parallel" fibers (deviating less than $\pm 45^{\circ}$ from the longitudinal axis), 2) perpendicular fibers, (deviating between $46^{\circ}$ and $90^{\circ}$ or $-46^{\circ}$ to $-90^{\circ}$ from the longitudinal axis) representing circular or radial fibers, and $\mathbf{3}$ ) fibers shorter than $27 \mu \mathrm{m}$ (not oriented parallel with the sectioning plane) representing circular, radial or wavy longitudinal fibers (arrows point at a longitudinal collagen fiber. Bar: $25 \mu \mathrm{m})$. 
the CI-patients (Table 5). A polymorphism demonstrated in the TGF-1 $\beta$ gene in CI-patients [12] may also be relevant as the TGF- $\beta$ pathway is involved in the synthesis of several extracellular macromolecules that interact with collagen.

An explanation for the increased collagen tensile strength $\left(S_{\max }\right)$ and stiffness $\left(S_{\max }^{\prime}\right)$ in the $\mathrm{CI}$ group is not obvious. Differences in collagen fiber orientation might affect the mechanical strength. However, the fraction of collagen fibers oriented "parallel" with the direction of the mechanical testing did not differ between groups (Table 5). Other causes for the difference in collagen strength may reside in differences in the turnover rate of various processes of aging and cross-linking of collagen, or in different interactions between collagen and other extracellular matrix components.

An interesting discovery is the significantly higher portion of collagen fibers, which could not be followed in the plane of sectioning in the CI group, compared with controls. One may speculate that patients with CI have a different collagen fiber orientation. Further investigation on this finding could involve intensive study of collagen fibers in a 3-dimensional reconstruction as collagen fibers are oriented in several directions.

The major strengths of this study are the very restrictive selection of CI patients and the combined application of biomechanical, histological and biochemical analyses. Furthermore, the biopsies were obtained 15 $\mathrm{mm}$ deep in the cervical stroma as compared to the superficial biopsies studied by Petersen et al. [13] and Rechberger et al. [25].

A limitation of the study is the possible bias induced by changed extracellular matrix after previous cerclage treatment of the CI-patients. One could also argue that some relevant anatomical parts of the cervix were not examined. These include the proximal parts of the cervices and parts near the lateral surface of the cervix; however, no difference in smooth muscle cells $15 \mathrm{~mm}$ proximal from the epithelium was found between CI and controls.

Before excluding congenital abnormalities as important for the development of $\mathrm{CI}$ one could wonder why cervical volumes have never been assessed in women with CI. They might have a relative cervical hypoplasia, which can be identified by ultrasound or MRI examinations. Such studies should be conducted in the near future.

Furthermore, it has been suggested that CI could be part a genetic condition as $25 \%$ of CI patients had a firstdegree relative with the condition [12]; however, the risk of recall bias was not explained in the given reference.

\section{Conclusions}

In conclusion, cervical insufficiency does not appear to be associated with a constitutionally low cervical collagen concentration or collagen of inferior mechanical quality. Furthermore, the results do not support the hypothesis that a biomechanically weak "muscular cervix" is a cause of CI.

\section{Acknowledgements}

We are deeply grateful to all the women who donated tissue samples to the present study and to the staff at the Outpatient Clinic, Department of Obstetrics and Gynecology, Aarhus University Hospital and Regional Hospital of Randers who assisted at the sample procedure. Special gratitude to Niels Jørgen Secher, Gitte Eriksen and Pinar Bor for help with the sampling procedure, and Jesper Skovhus Thomsen for help when needed. The skilled technical assistance of Kirsten Zeeberg, Jytte Utoft, Eva K. Mikkelsen and Inger Merete S. Paulsen is greatly appreciated. We thank Aarhus University Hospital, Skejby Foundation, Aarhus University Research Foundation and Institute of Experimental Clinical Research, Aarhus University Hospital, Skejby for financial support.

\section{Author details}

'Department of Obstetrics and Gynecology, Aarhus University Hospital, Skejby, DK-8200 Aarhus N, Denmark. ${ }^{2}$ Institute of Anatomy, Aarhus University, DK-8000 Aarhus C, Denmark.

\section{Authors' contributions}

$B O, G \varnothing, A B, H O, C C D$ and $N U$ contributed to the design of the study. The sample collection was carried out by $\mathrm{BO}$ and $\mathrm{G} \varnothing$. Biomechanical and histological analyses were done by $B O, A B$ and $C C D$. $B O, G \varnothing, A B, C C D$ and $\mathrm{NU}$ participated in the data analyses. The manuscript was written by $\mathrm{BO}$ with revision by $N U, G \varnothing, A B, C C D$ and $H O$. All authors have read and approved the final manuscript.

\section{Competing interests}

The authors declare that they have no competing interests.

Received: 13 January 2010 Accepted: 30 July 2010

Published: 30 July 2010

\section{References}

1. ACOG Practice Bulletin. Cervical insufficiency. Obstet Gynecol 2003, 102:1091-1099.

2. Parisi VM: Cervical incompetence and preterm labor. Clin Obstet Gynecol 1988, 31:585-598.

3. lams JD, Johnson FF, Sonck J, Sachs L, Gebauer C, Samuels P: Cervical competence as a continuum: A study of ultrasonographic cervical length and obstetric performance. Am J Obstet Gynecol 1995, 172:1097-1106.

4. Word RA, Li XH, Hnat M, Carrick K: Dynamics of cervical remodeling during pregnancy and parturition: mechanisms and current concepts. Semin Reprod Med 2007, 25:69-79.

5. Danforth DN: The fibrous nature of the human cervix, and its relation to the isthmic segment in gravid and nongravid uteri. Am J Obstet Gynecol 1947, 53:541-557.

6. Romero R, Mazor M, Munoz H, Gomez R, Galasso M, Sherer DM: The preterm labor syndrome. Ann N Y Acad Sci 1994, 734:414-429.

7. Vidaeff A, Ramin S: From Concept to Practice: The Recent History of Preterm Delivery Prevention. Part I: Cervical Competence. Amer J Perinatol 2006, 23:003-014.

8. Warren JE, Nelson LM, Stoddard GJ, Esplin MS, Varner MW, Silver RM: Polymorphisms in the promoter region of the interleukin-10 (IL-10) gene in women with cervical insufficiency. Am J Obstet Gynecol 2009, 201:372-375

9. De Vos M, Nuytinck L, Verellen C, De PA: Preterm premature rupture of membranes in a patient with the hypermobility type of the EhlersDanlos syndrome. A case report. Fetal Diagn Ther 1999, 14:244-247.

10. Toriello HV, Glover TW, Takahara K, Byers PH, Miller DE, Higgins JV, Greenspan DS: A translocation interrupts the COL5A1 gene in a patient with Ehlers-Danlos syndrome and hypomelanosis of Ito. Nat Genet 1996, 13:361-365. 
11. Nicholls AC, Oliver JE, McCarron S, Harrison JB, Greenspan DS, Pope FM: An exon skipping mutation of a type $\mathrm{V}$ collagen gene (COL5A1) in EhlersDanlos syndrome. J Med Genet 1996, 33:940-946.

12. Warren JE, Silver RM, Dalton J, Nelson LT, Branch DW, Porter TF: Collagen $1 \mathrm{~A} 1$ and Transforming Growth Factor-\{beta\} Polymorphisms in Women With Cervical Insufficiency. Obstet Gynecol 2007, 110:619-624.

13. Petersen LK, Uldbjerg N: Cervical collagen in non-pregnant women with previous cervical incompetence. Eur J Obstet Gynecol Reprod Biol 1996, 67:41-45.

14. Maul H, Mackay L, Garfield RE: Cervical ripening: biochemical, molecular, and clinical considerations. Clin Obstet Gynecol 2006, 49:551-563.

15. Schlembach D, MacKay L, Shi L, Maner WL, Garfield RE, Maul H: Cervical ripening and insufficiency: From biochemical and molecular studies to in vivo clinical examination. Eur J Obstet Gynecol Reprod Biol 2009, 144 S70-S76.

16. Leppert PC, Yu SY, Keller S, Cerreta J, Mandl I: Decreased elastic fibers and desmosine content in incompetent cervix. Am J Obstet Gynecol 1987, 157:1134-1139.

17. Roddick JWJ, Buckingham JC, Danforth DN: The muscular cervix-a cause of incompetency in pregnancy. Obstet Gynecol 1961, 17:562-565.

18. Buckingham JC, Buethe RAJ, Danforth DN: Collagen-Muscle Ratio in Clinically Normal and Clinically Incompetent Cervicis. Am J Obstet Gynecol 1965, 91:232-237.

19. Oxlund BS, Ortoft G, Bruel A, Danielsen CC, Bor P, Oxlund H, Uldbjerg N: Collagen concentration and biomechanical properties of samples from the lower uterine cervix in relation to age and parity in non-pregnant women. Reprod Biol Endocrinol 2010, 8:82.

20. Woessner JF: Determination of hydroxyproline in connective tissues. Joynson-Bruvvers, Oxford 1976, 227-233.

21. Danielsen CC, Andreassen TT: Mechanical properties of rat tail tendon in relation to proximal-distal sampling position and age. J Biomech 1988, 21:207-212.

22. Neuman R, Logan M: The determination of collagen and elastin in tissues. J Biol Chem 1950, 186:549-556.

23. Gunnersen $H$, Jensen EB: The efficiency of systematic sampling in stereology and its prediction. J Microsc 1987, 147:229-263.

24. Puchtler H, Waldrop FS, Valentine LS: Polarization microscopic studies of connective tissue stained with picro-sirius red FBA. Beitr Pathol 1973, 150:174-187.

25. Rechberger $\mathrm{T}$, Uldbjerg $\mathrm{N}$, Oxlund $\mathrm{H}$ : Connective tissue changes in the cervix during normal pregnancy and pregnancy complicated by cervical incompetence. Obstet Gynecol 1988, 71:563-567.

26. House M, Kaplan DL, Socrate S: Relationships Between Mechanical Properties and Extracellular Matrix Constituents of the Cervical Stroma During Pregnancy. Semin Perinatol 2009, 33:300-307.

27. Petersen $L K$, Oxlund $H$, Uldbjerg $N$, Forman $A$ : In vitro analysis of muscular contractile ability and passive biomechanical properties of uterine cervical samples from nonpregnant women. Obstet Gynecol 1991, 77:772-776.

doi:10.1186/1477-7827-8-92

Cite this article as: Oxlund et al:: Cervical collagen and biomechanical strength in non-pregnant women with a history of cervical insufficiency. Reproductive Biology and Endocrinology 2010 8:92.

\section{Submit your next manuscript to BioMed Central and take full advantage of:}

- Convenient online submission

- Thorough peer review

- No space constraints or color figure charges

- Immediate publication on acceptance

- Inclusion in PubMed, CAS, Scopus and Google Scholar

- Research which is freely available for redistribution

Submit your manuscript at www.biomedcentral.com/submit 